\title{
Perbedaan Kecepatan Kesembuhan Anak Gizi Buruk yang Diberi Modisco Susu Formula dan Modisco Susu Formula Elemental Di RSU dr. Soetomo Surabaya
}

\author{
Roedi Irawan
}

Latar belakang. Dalam tata laksana kasus gizi buruk yang dirawat di rumah sakit memerlukan nutrisi yang terbaik dalam mempercepat kesembuhannya terhadap penyakit utama maupun upaya dalam memperbaiki status gizi. Oleh karena itu sampai saat ini masih dicari dan diujicobakan beberapa nutrisi yang tepat dan terbaik pada anak gizi buruk.

Tujuan. Penelitian ini bertujuan mempelajari perbedaan kecepatan kesembuhan pada anak gizi buruk yang diberi modisco susu formula dan modisco susu formula elemental. Metoda. Pengambilan sampel secara acak buta ganda dengan uji eksperimental. Kriteria inklusi yaitu anak umur 1-3 tahun dengan status gizi buruk dan menderita penyakit infeksi. Subyek penelitian diambil dari 112 populasi anak gizi buruk yang menderita berbagai macam penyakit infeksi sebagai penyakit primer.

Hasil. Didapatkan 49 anak diantaranya yang masuk kriteria inklusi, kemudian dibagi dalam 2 kelompok: 27 anak diberi modisco susu formula dan 22 anak diberi modisco susu formula elemental. Terdapat perbedaan bermakna antara berat badan sebelum dan sesudah penelitian pada kedua kelompok $(\mathrm{P}<0,05)$. Perbedaan bermakna pada nilai $\mathrm{Z}$ skor berat badan terhadap tinggi badan $(\mathrm{BB} / \mathrm{TB})$ antara kelompok yang diberi modisco susu formula dan modisco susu formula elemental $(\mathrm{P}<0,05)$.

Kesimpulan. Kelompok yang diberi modisco susu formula elemental menunjukkan penyembuhan yang lebih cepat dibanding kelompok yang diberi modisco susu formula.

Kata kunci: gizi buruk, modisco, susu formula elemental, kecepatan kesembuhan

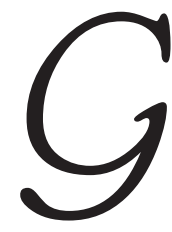

izi buruk adalah kelainan gizi yang disebabkan adanya gangguan gizi yang dapat berupa kekurangan zat gizi dari salah satu/ lebih bahan makanan. ${ }^{1} \mathrm{Hal}$

\footnotetext{
Alamat korespondensi:

Dr. Roedi Irawan, Sp.A.

Divisi Nutrisi dan Penyakit Metabolik Bagian Ilmu Kesehatan Anak FK-TDC UNAIR RS Dr. Soetomo Surabaya. Jl Prof. Dr. Moestopo 68. Surabaya, 60132. 40061/3916.
}

tersebut dapat terjadi karena makanan yang dimakan tidak cukup, baik secara kualitas maupun kuantitas atau karena kebutuhan yang meningkat, pengeluaran yang berlebih, walaupun makanan yang dimakan sudah mencukupi. ${ }^{2}$ Telah lama diketahui bahwa antara gizi buruk dan infeksi mempunyai keterkaitan yang erat. Infeksi yang berat dapat memperburuk keadaan gizi dan sebaliknya pada keadaan terinfeksi akan berpengaruh negatif terhadap daya tahan tubuh. Gangguan gizi dan infeksi yang terjadi bersamaan memberikan 
prognosis buruk bila dibandingkan terjadi terpisah. ${ }^{3}$ Dukungan nutrisi yang tidak memadai merupakan penyebab utama terjadinya malnutrisi di rumah sakit (hospital malnutrition), selain itu juga karena perhatian para tenaga kesehatan terhadap perbaikan nutrisi masih kurang. ${ }^{4}$ Faktor risiko terjadinya malnutrisi rumah sakit pada pasien yang menjalani rawat inap diantaranya adalah asupan kurang, usia, status gizi saat awal dirawat, penyakit infeksi akut/ kronis, keganasan, atau timbulnya komplikasi. ${ }^{5}$

Pengertian modisco (modification dried skim cotton oil) adalah minuman tinggi kalori yang terdiri dari susu, gula dan minyak/mentega digunakan untuk mengobati gangguan gizi berat pada anak dengan hasil yang cukup memuaskan. Susu yang digunakan bisa susu formula biasa atau susu formula elemental. Susu formula elemental merupakan nutrisi dengan formula khusus untuk anak yang memerlukan energi siap pakai karena mengalami gangguan pencernaan dan gangguan penyerapan, bisa terbuat dari susu sapi ataupun susu kedelai dan telah mengalami proses protein hydrolisa, mengandung lemak medium chain triglyserida, dan karbohidrat polimer. ${ }^{6,7}$

Tujuan penelitian ini untuk mempelajari perbedaan kecepatan kesembuhan anak gizi buruk yang diberi modisco dengan susu formula dan diberi modisco dengan susu formula elemental

\section{Bahan dan cara}

Penelitian ini merupakan penelitian uji eksperimental, pemberian perlakuan secara acak buta ganda. Kriteria inklusi, berumur 1-3 tahun, menderita gizi buruk, menderita infeksi, mendapat modisco susu formula atau modisco susu formula elemental, setelah keadaan klinis stabil. Kriteria eksklusi bila ada kelainan bawaan, menderita infeksi berat, dan meninggal. Cara kerja, ditanyakan tentang identitas meliputi nama, tanggal lahir, jenis kelamin, dan alamat. Setiap pasien ditentukan berat badan, tinggi badan dan Lingkar lengan atas sebanyak dua kali, yaitu pada saat awal dirawat dan saat keluar dari rumah sakit atau pada hari perawatan ke empat belas. Subyek dibagi 2 kelompok, kelompok I diberi modisco dengan susu formula dan kelompok II diberi modisco dengan susu formula elemental. Penelitian dilaksanakan dalam waktu 6 bulan, dilakukan di ruang rawat inap anak dan unit perawatan intensif anak RSU. Dr.Soetomo Surabaya. Analisis statistik dilakukan dengan uji chi square, uji t dan uji Manova.

\section{Hasil}

Pada penelitian ini didapatkan 49 subyek yang memenuhi syarat untuk dianalisis, terdiri dari perempuan 27 orang dan laki-laki 22 orang.

Dari 49 pasien gizi buruk (Tabel 1), yang mendapat modisco susu formula sebanyak 27 anak dan modisco susu formula elemental 22 anak. Dari kelompok yang mendapat susu formula perempuan 18 orang $(66,7 \%)$ lebih banyak dari laki-laki 9 orang $(33,3 \%)$. Sedangkan 22 anak kelompok yang mendapat susu formula elemental laki-laki 13 orang $(59,1 \%)$ lebih banyak daripada perempuan yaitu 9 orang $(40,9 \%)$.

Tabel 1. Karakteristik subyek.

\begin{tabular}{lcc}
\hline Parameter & $\begin{array}{c}\text { Kelompok } \\
\text { susu } \\
\text { formula }\end{array}$ & $\begin{array}{c}\text { Kelompok } \\
\text { susu } \\
\text { formula } \\
\text { Elemental }\end{array}$ \\
\hline Jenis Kelamin & & \\
- Laki-laki & 18 & 9 \\
- Perempuan & 9 & 13 \\
Umur (bulan) & & \\
12-17 & 10 & 14 \\
18-23 & 9 & 3 \\
24-29 & 2 & 4 \\
30-36 & 6 & 1 \\
Status gizi & & \\
- Kwashiorkor & 6 & 2 \\
- Marasmus Kwashiorkor & 18 & 17 \\
- Marasmus & 3 & 3 \\
\hline
\end{tabular}

Kelompok umur penderita gizi buruk terbanyak yang diberikan modisco adalah pada umur $12-17$ bulan (24 penderita), kelompok pemberian dengan susu formula $(37,1 \%)$ dan susu formula elemental $(63,6 \%)$.

Penderita gizi buruk terbanyak jenis marasmus kwasiorkor (35 anak), marasmus (6 anak), dan kwasiorkor (8 anak).

Pada Tabel 2 ini menunjukkan bahwa pasien gizi 
buruk terbanyak disertai diare (22 anak), dengan perincian diare akut 10 dan diare kronis 12 anak. Demikian pula dengan 11 anak yang menderita infeksi saluran nafas bawah terdiri dari bronkopnemoni dan bronkiolitis.

Hasil penelitian ini menunjukkan bahwa terdapat perbedaan bermakna antara selisih kenaikan berat badan kelompok susu formula dan kelompok susu formula elemental, pada awal dan akhir pemberian. (Tabel 3)

Dari penelitian ini dijumpai selisih kenaikan bermakna nilai $Z$-score perbandingan $\mathrm{BB}$ terhadap $\mathrm{TB}$ antara kelompok susu formula dan kelompok susu formula elemental. (Tabel 4)

Tabel 5. menunjukkan perbedaan bermakna pada lama sembuh penyakit utama dan lama rawat, tetapi terdapat perbedaan bermakna antara kecepatan sembuh pasien gizi buruk sebelum dan sesudah pemberian susu formula atau susu formula elemental.

Hasil uji Manova pada Tabel 6 tidak ada perbedaan bermakna antara perbedaan kecepatan kesembuhan anak gizi buruk yang diberi modisco susu formula dengan modisco susu formula elemental.

Tabel 2. Diagnosis penyakit utama saat masuk rumah sakit di RSUP dr. Soetomo, tahun 2004.

\begin{tabular}{llcc}
\hline No & Diagnosis & $\begin{array}{c}\text { Modisco } \\
\text { Susu Formula }\end{array}$ & Susu Formula Elemental \\
\hline 1 & Diare akut & $6(22,2 \%)$ & $4(18,2 \%)$ \\
2 & Diare kronis & $7(25,9 \%)$ & $5(22,7 \%)$ \\
3 & Infeksi otak & $3(11,1 \%)$ & $2(9,1 \%)$ \\
4 & Infeksi saluran nafas atas & $1(3,7 \%)$ & $3(13,6 \%)$ \\
5 & Demam tipoid & $2(7,4 \%)$ & $2(9,1 \%)$ \\
6 & Tuberkulosis & $2(7,4 \%)$ & $0(0,0 \%)$ \\
7 & Infeksi saluran nafas bawah & $5(18,5 \%)$ & $6(27,3 \%)$ \\
8 & Demam berdarah dengue & $1(3,8 \%)$ & $0(0,0 \%)$ \\
\hline & Total & $27(100 \%)$ & $22(100 \%)$ \\
\hline
\end{tabular}

Tabel 3. Perbedaan antara berat badan awal dan berat badan akhir sesudah pemberian Modisco.

\begin{tabular}{|c|c|c|c|c|c|}
\hline \multirow[t]{3}{*}{ Parameter } & \multicolumn{4}{|c|}{ Modisco } & \multirow{3}{*}{ Nilai $P$} \\
\hline & \multicolumn{2}{|c|}{ Susu Formula } & \multicolumn{2}{|c|}{ Susu Formula Elemental } & \\
\hline & BB awal & BB akhir & BB awal & BB akhir & \\
\hline Rerata & 6,993 & 7,719 & 6,432 & 7,959 & $\mathrm{P}=0,001$ \\
\hline $\mathrm{SB}^{*}$ & 1,2779 & 1,5044 & 1,1890 & 1,8057 & \\
\hline Minimum & 4,6 & 5,3 & 4,4 & 5,1 & \\
\hline Maksimum & 9,5 & 10,0 & 8,5 & 9,7 & \\
\hline
\end{tabular}

* $\mathrm{SB}=$ simpang baku $\quad \mathrm{BB}=$ berat badan

Tabel 4. Berat badan terhadap tinggi badan sesudah pemberian Modisco.

\begin{tabular}{lccccc}
\hline \multirow{2}{*}{ Parameter } & \multicolumn{4}{c}{ Modisco } & \multirow{2}{*}{ Nilai P } \\
\cline { 2 - 4 } & \multicolumn{2}{c}{ Susu Formula } & \multicolumn{2}{c}{ Susu Formula Elemental } & \\
\cline { 2 - 4 } & BB/TB awal & BB/TB akhir & BB/TB awal & BB/TB akhir & P = 0,002 \\
Rerata & $-3,99$ & $-2,98$ & $-3,59$ & $-1,57$ & \\
SB* & 1,32 & 1,36 & 1,88 & 1,98 & \\
Minimum & $-4,30$ & $-3,90$ & $-3,90$ & $-3,80$ & \\
Maksimum & $-3,50$ & $-3,60$ & $-3,20$ & $-1,90$ & \\
\hline
\end{tabular}

* $\mathrm{SB}=$ simpang baku $\quad \mathrm{BB}=$ berat badan 
Sari Pediatri, Vol. 8, No. 3, Desember 2006

Tabel 5. Prognosis pasien malnutrisi sesudah pemberian Modisco di RSUP Dr. Soetomo, tahun 2004

\begin{tabular}{lccc}
\hline \multirow{2}{*}{ Prognosis } & \multicolumn{2}{c}{ Modisco } & \\
\cline { 2 - 3 } & Susu Formula & Susu Formula Elemental & \multirow{2}{*}{ Nilai P } \\
\cline { 2 - 3 } & $(\mathrm{X} \pm \mathrm{SB})$ & $(\mathrm{X} \pm \mathrm{SB})$ & \\
\hline Sembuh & & & \\
penyakit utama (hari) & $11,11 \pm 7,55$ & $1,50 \pm 8,36$ & $\mathrm{P}=0,865$ \\
Lama rawat (hari) & $20,50 \pm 10,08$ & $20,47 \pm 8,37$ & $\mathrm{P}=0,995$ \\
Kecepatan sembuh (\%) & $13,88 \pm 7,88$ & $24,04 \pm 10,96$ & $\mathrm{P}=0,001$ \\
\hline
\end{tabular}

Tabel 6. Kecepatan kesembuhan malnutrisi sesudah pemberian Modisco.

\begin{tabular}{|c|c|c|c|}
\hline \multirow{3}{*}{ Karakteristik } & \multicolumn{2}{|c|}{ Kecepatan kesembuhan (\%) } & \multirow{3}{*}{ Nilai $\mathrm{p}^{*}$} \\
\hline & $\begin{array}{l}\text { Modisco susu } \\
\text { Formula }\end{array}$ & $\begin{array}{c}\text { Modisco susu Formula } \\
\text { elemental }\end{array}$ & \\
\hline & $(\mathrm{x} \pm \mathrm{SB})$ & $(\mathrm{x} \pm \mathrm{SB})$ & \\
\hline \multicolumn{4}{|l|}{ Jenis kelamin } \\
\hline - Laki-laki & $53,4 \pm 25,7$ & $77,4 \pm 15,1$ & 0,437 \\
\hline - Perempuan & $46,9 \pm 17,4$ & $61,7 \pm 23,3$ & \\
\hline Umur (bulan) & $20,3 \pm 7,6$ & $16,8 \pm 5,21$ & 0,832 \\
\hline \multicolumn{4}{|l|}{ Status gizi } \\
\hline - Marasmus & $72,0 \pm 16,5$ & $43,0 \pm 13,2$ & 0,232 \\
\hline - Kwashiorkor & $50,7 \pm 18,3$ & $84,5 \pm 2,1$ & \\
\hline - Marasmus Kwashiorkor & $44,8 \pm 19,6$ & $74,3 \pm 17,9$ & \\
\hline Lama rawat & $20,5 \pm 10,5$ & $20,4 \pm 8,3$ & 0,711 \\
\hline Sembuh penyakit utama & $11,1 \pm 7,5$ & $11,5 \pm 8,3$ & 0,911 \\
\hline
\end{tabular}

*Uji Manova

\section{Pembahasan}

Selama perawatan di rumah sakit, seorang anak seringkali dianggap layak menjadi kekurangan gizi karena anak kurang/malas makan, sehingga angka kejadian kurang giziselama perawatan cukup tinggi. Keadaan ini menyebabkan meningkatnya risiko kecacatan, kematian, dan juga mempunyai potensi kerugian materi. ${ }^{6,8}$

Pada penelitian ini gizi buruk banyak diderita oleh anak perempuan dan terbanyak pada umur $12-17$ bulan. Tidak didapatkan perbedaan kuantitatif pada jenis kelamin penderita gizi buruk yang dirawat di rumah sakit. Baker $S^{9}$ mengemukakan bahwa jenis kelamin bukan merupakan faktor penyebab malnutrisi, walaupun malnutrisi di RSU Dr. Soetomo lebih banyak terjadi pada anak perempuan dari pada lakilaki. ${ }^{4}$ Rerata umur kelompok susu formula adalah 20 bulan, lebih tua dibandingkan kelompok susu formula elemental yaitu 16 bulan. Pada anak umur $1-3$ tahun lebih banyak yang menderita malnutrisi, baik malnutrisi primer karena asupan yang tidak adekuat maupun malnutrisi sekunder karena penyakit utama yang diderita. Malnutrisi banyak terjadi penderita berumur 0-22 bulan dengan malnutrisi akut 54\%.8, Umur saat pemberian modisco tidak berpengaruh terhadap peningkatan berat badan. ${ }^{4}$

Terbanyak anak dengan malnutrisi menderita diare kronis jumlah pasien diare terdapat sama banyaknya antara kelompok susu formula dengan kelompok susu formula elemental. Hal ini menunjukkan bahwa penderita gizi buruk dengan diare akut menempati urutan teratas $(32 \%)$ dari sepuluh penyakit terbanyak. Hal ini menunjukkan bahwa kasus diare harus tetap diwaspadai dan perlu mendapat pencegahan maupun penanganan lebih baik di Surabaya.

Selisih kenaikan berat badan awal dan berat badan akhir antara kelompok modisco susu formula dan 
kelompok susu formula elemental menunjukkan perbedaan. Hal ini oleh karena kemampuan absorbsi usus pada anak gizi buruk lebih baik pada pemberian susu formula elemental dari pada susu formula biasa. Menurut data kasus kurang kalori protein berat (marasmus, marasmus kwasiorkor dan kwasiorkor) yang dirawat di RSU Dr. Soetomo setelah diberi modisco terdapat perbedaan peningkatan berat badan rata-rata / hari. ${ }^{6}$

Pada penelitian ini menunjukkan terdapat selisih kenaikan nilai $Z$-Score Index BB/TB yang bermakna antara kelompok sesudah pemberian modisco susu formula dan kelompok sesudah pemberian modisco susu formula elemental. Ternyata nilai $Z$-Score Index $\mathrm{BB} / \mathrm{TB}$ juga meningkat lebih baik sejalan dengan meningkatnya berat badan anak gizi buruk pada kelompok dengan modisco susu formula elemental, karena susu formula elemental lebih mudah diserap dan lebih kecil timbulnya efek samping muntah/ diare.

Indikator kecepatan kesembuhan menggunakan parameter berat badan, selisih berat badan awal (saat masuk rumah sakit) dan berat badan akhir (saat keluar rumah sakit) dinyatakan dalam kg dan selisihnya dikonversikan dalam persen. Kecepatan kesembuhan anak gizi buruk pada kelompok modisco susu formula dengan rerata $13,88 \%$ dibandingkan kelompok modisco susu formula elemental 24,4\%. Kecepatan kesembuhan ini mempunyai pengertian terhadap kecepatan perbaikan status gizi anak, yaitu perubahan status gizi buruk pada saat masuk rumah sakit dan berubah menjadi status gizi kurang saat perawatan di rumah sakit.

\section{Kesimpulan}

Dari penelitian ini dapat diambil kesimpulan, bahwa terdapat selisih kenaikan berat badan awal dan berat badan akhir pasien gizi buruk selisih nilai $Z$-score $\mathrm{BB} / \mathrm{TB}$ antara kelompok modisco susu formula dan kelompok modisco susu formula elemental. Demikian pula kecepatan kesembuhan pada anak gizi buruk yang diberi modisco dengan susu formula elemental lebih cepat dibanding yang diberi modisco dengan susu formula.

\section{Daftar Pustaka}

1. Hidayat, B. Beberapa aspek klinis malnutrisi pada anak. Dalam: Ranuh IG.N, E Sarwono, S Untario, P Soeparto, G Santoso, penyunting. Gizi dengan beberapa masalah. Continuing education. Ilmu Kesehatan Anak No.3. SIC Surabaya 1981. h. 23-42.

2. Krause MV, LK Mohan. Nutritional deficiency disease. In: Krause MV, LK Mohan, penyunting. Food, nutrition, and diet therapy. Edisi ke-9. W.B. Saunders Co. Philadelphia 1979. h. 387-420.

3. Alisjahbana A. Gizi kurang dan infeksi. Dalam : Kardjati S., Alisjahbana A., Kusinja, penyunting. Aspek kesehatan gizi dan balita. Yayasan Obor Indonesia Jakarta 1985. h. 53-70.

4. Irawan R. Data distribusi penderita anak di Lab/SMF Ilmu Kesehatan Anak RSU. Dr. Soetomo-FK.Unair (Data laporan tahunan) 2000.

5. Roubenoff, R 1987. Malnutrition among hospitalized patients. Arch Intern Med 147: 1462-5.

6. Hidayat B, I Rudi, NH Siti. Nutrisi pada anak sakit. Dalam: Kapita selekta Ilmu Kesehatan Anak. Continuing education Ilmu Kesehatan Anak ke-32 SIC Surabaya 2002. h. 41-54.

7. Nasar, SS. Pengkajian status nutrisi anak di klinik. Disampaikan pada Kongres Nasional Ilmu Kesehatan Anak X, Bukittinggi, 16-20 Juni 1996.

8. Mc Laren Ds. Nutritional assessment and surveyllance. Dalam: Mc Laren, penyunting. Text book of Paediatric Nutrition. Edisi ke-3. Churchill Livingstone. Edinburgh 1991. h. 309-317.

9. Baker SS. Protein energy malnutrition in the hospitalized pediatric patient. Dalam: Walker WA, JP, Watkins, penyunting. Nutrition in pediatrics: basic science and clinical applications. Edisi ke-2. BC.Decker. Pub; London 1997. h. 162-8 